IZA DP No. 6909

Aging and Productivity: Evidence from Piece Rates

Tuomas Pekkarinen

Roope Uusitalo

October 2012

Forschungsinstitut zur Zukunft der Arbeit Institute for the Study of Labor 


\title{
Aging and Productivity: Evidence from Piece Rates
}

\author{
Tuomas Pekkarinen \\ Aalto University, \\ IZA and IFAU \\ Roope Uusitalo \\ University of Helsinki, \\ IZA and IFAU
}

\section{Discussion Paper No. 6909 \\ October 2012}

\author{
IZA \\ P.O. Box 7240 \\ 53072 Bonn \\ Germany \\ Phone: +49-228-3894-0 \\ Fax: +49-228-3894-180 \\ E-mail: iza@iza.org
}

Any opinions expressed here are those of the author(s) and not those of IZA. Research published in this series may include views on policy, but the institute itself takes no institutional policy positions. The IZA research network is committed to the IZA Guiding Principles of Research Integrity.

The Institute for the Study of Labor (IZA) in Bonn is a local and virtual international research center and a place of communication between science, politics and business. IZA is an independent nonprofit organization supported by Deutsche Post Foundation. The center is associated with the University of Bonn and offers a stimulating research environment through its international network, workshops and conferences, data service, project support, research visits and doctoral program. IZA engages in (i) original and internationally competitive research in all fields of labor economics, (ii) development of policy concepts, and (iii) dissemination of research results and concepts to the interested public.

IZA Discussion Papers often represent preliminary work and are circulated to encourage discussion. Citation of such a paper should account for its provisional character. A revised version may be available directly from the author. 
IZA Discussion Paper No. 6909

October 2012

\section{ABSTRACT}

\section{Aging and Productivity: Evidence from Piece Rates}

We evaluate the effects of aging on productivity using piece-rate earnings as a proxy for worker output. Our data contain the population of Finnish blue collar workers in 61 different industries during 1990-2002. A unique feature of the data is that we can observe the exact hours worked on piece rates and on fixed time rates as well as earnings under both performance schemes. We account for the selection into piece rates by using firm-level changes in pay systems as instruments for the probability of working on piece rates. A subset of workers also receive both piece rates and time rates within the same quarter. For these workers, we can directly compare the age profile of hourly earnings under piece rates and fixed rates. The results indicate that productivity increases with age until age 40 after which it stays roughly constant. Wage growth is faster than productivity growth for young workers but after age 40 both wages and productivity grow approximately at the same rate.

JEL Classification: J1, J24, J33

Keywords: piece rates, productivity, aging

Corresponding author:

Tuomas Pekkarinen

Aalto University

School of Economics

Department of Economics

Box 21210

00076 Aalto

Finland

E-mail: tuomas.pekkarinen@aalto.fi 


\section{Introduction}

Population aging in the industrialized countries has raised concerns about its effects on productivity growth. ${ }^{1}$ Underlying these concerns is the assumption that worker productivity declines with age. Yet, a priori, it is not clear how aging should affect worker productivity. While physical strength, some cognitive skills and the capacity to learn deteriorate with age, accumulated work experience may mitigate the negative effects of aging on productive skills. How important all these factors are, and hence the net effect of aging on productivity, is still an open question.

In this paper, we study the effect of aging on worker productivity at the individual level using piece-rate earnings as a proxy for productivity. Unlike fixed time-rate wages, the piece rates are directly determined by worker's output. We use payroll data that cover the whole blue-collar worker population in the Finnish manufacturing industries in 1990-2002. In these data we observe the exact earnings and the number of hours worked under both time-rate and piece-rate compensation schemes for each worker. The panel structure of the data allows us to follow workers over time and to examine the changes in their hourly earnings as they get older. A subset of workers in the data also work under both piece and fixed rate schemes, often during the same quarter. For these workers, we can directly observe the difference between piece-rate and time-rate earnings at the same point in time directly and calculate the age profile of the within-worker gap between productivity and wages.

Earlier studies on the effect of aging on productivity have followed several stategies. In some occupations direct measures of individual productivity are available and age-productivity profiles can be calculated in a straightforward way. ${ }^{2}$ Sometimes direct measures of productivity are available for

\footnotetext{
${ }^{1}$ See papers by Feyrer 2007 and Tang and MacLeod 2006 on the effects of population aging on aggregate productivity growth in the United States and Canada, respectively.

${ }^{2}$ Oster and Hamermesh 1998 as well as Weinberg and Galenson 2005 focus on aca-
} 
more representative samples of workers at team level (eg. Borsch-Supan and Weiss |2008|). Also individual wages and supervisor performance evaluations have been used as productivity measures. ${ }^{3}$ More recently, the use of linked employer-employee data has become common in the field. Authors such as Hellerstein et al. |1999|, Crépon et al. |2003|, Ilmakunnas and Maliranta $|2005|$ as well as Dostie |2011| use firm-level information to estimate the effect of workforce composition on the firm productivity. Most of these studies suggest that productivity of the older workers is lower than that of the prime-age workers.

Although these studies provide important insights on the effects of aging on productivity, they are in many ways problematic. Direct information on individual output is available only for few professions and the results from these studies are hard to generalise. Supervisor evaluations could be sufficient statistics for worker's productivity in ideal circumstances but it is far from clear that the supervisor's objectively evaluate the worker's current productivity. Studies that estimate the effect of workforce characteristics on firm productivity essentially assume that workers are randomly allocated to firms. In reality, for example the average age of the workers in the firm is likely to be endogeneous as it depends on the past firing and hiring rates which may be related to profitability of the firm or productivity of its workers.

The approach chosen in this paper bears some similarities to the early work by Lazear and Moore $|1984|$ who use self-employment earnings as a proxy for productivity and Lazear |2000| study that is based on data from a single firm. In our study we measure productivity by piece rates using data that cover a whole industrial sector which has several advantages. First, the data that we use contain information on workers employed in a wide variety of

demics; Galenson and Jensen $[2001 \mid$ study the careers of a number of great painters; Fair 1994 and Van Ours [2009] study of the age-productivity profiles of track and field athletes.

${ }^{3}$ Influential early studies by Medoff and Abraham [1980] and Medoff and Abraham 1981 show that worker's job tenure is negatively associated with supervisor evaluations. Flabbi and Ichino $|2001|$ repliacte the analysis in a different context with very similar results. 
tasks and industries and is therefore more representative than studies based on narrowly defined occupations or single firms. Second, piece rates provide us a metric that makes productivity comparable across tasks and allows us to compare age-productivity profiles in different tasks and industries. Third, unlike in the case of average hourly earnings or supervisor performance evaluations, the standard agency problems are absent under piece rates that are directly determined by worker's individual output. Finally, as we can focus on output at indivudual level, we do not have to assume that firms hire and fire workers of different ages randomly.

The use of piece rates as a productivity proxy naturally also has its caveats. First, the piece rates are not used in all industries and tasks. In our data, we also observe a clear declining trend in the use of piece rates. Yet, more problematic is that even within tasks and industries, piece-rate assignments are not randomly allocated to workers. Our solution to this difficult problem is to use year to year variation in the use of piece rates at the firm level to construct selectivity corrected estimates for the effect of age on piece-rate earnings.

Our results show that worker productivity increases until age 40 after which there is only a modest decline in the years immediately before retirement. The wages of young workers increase more rapidly than their productivity so that while young workers are initailly "cheaper" in terms of their wage productivity gap, this advantage disappears by the age 45 after which productivity and wages follow the same age profile.

\section{Data}

We use data from the wage records of the Confederation of Finnish Industry and Employers. For the Finnish manufacturing industries, the data cover virtually all large firms and all workers in these firms. We focus on bluecollar workers and have data on the entire blue-collar population from 1990 
to 2002 .

Each observation in the data contains the hours worked and earnings within the last quarter of a calendar year. After eliminating some observations due to missing information and trimming observations that exceed or are below the annual earnings median by a factor 10 to remove outliers due to coding errors, we have a panel of 2,737,096 employee-year observations representing 545,872 workers from 5,105 firms in 61 industries. The average number of years of obervations per worker is 8.47 .

\subsection{Payment schemes in Finnish manufacturing}

The Finnish manufacturing industries are unionized and the general guidelines on wage determination are defined in the industry-level collective agreements. These collective agreements allow the firms to choose from three different contracts: fixed rates, piece rates and reward rates. The spirit of the collective agreement is that the payment method should be determined by the characteristics of the tasks performed by the worker not by the characteristics of the worker.

On time rates, workers are paid fixed hourly wages although contracts do have provisions for discretionary bonuses. For example in the technology industry, which employs the largest number of workers, this bonus can amount to $2 \%-17 \%$ of the job-specific minimum wage. The final level of the time rates is deterimined at the local level so that there is considerable variation across workers and firms in time rate wages even within detailed occupations.

On piece rates, workers are paid purely based on individual output. The collective agreement indicates that piece rates should be used on clearly specified task assignments, and that payment should be based on output measures such as units, kilograms or meters produced. The union contracts contain detailed task descriptions and unit prices in various tasks. General wage increases typically affect directly these task-specific rewards. Piece rates are currently the least common payment scheme in the industry. Only $15 \%$ 
(17\% for women) of total hours worked are rewarded based on piece rates.

The final compensation contract in the Finnish manufacturing industries is reward rates, which are a mix of piece rates and fixed rates, and could also include a team-based bonus. Unfortunately, the payroll records from the Confederation do not separate the part of reward-rate pay that is based on output from the part that is fixed. For this reason, reward rate earnings are omitted from the analysis.

\subsection{The use of piece rates}

A unique feature in these data is that we can observe the exact number of hours that the individual has worked under each payment scheme in each year. This information reveals that 377,527 (69\%) workers in our data never received piece rates. Only 15,805 (3\%) worked exclusively on piece-rate contracts. Altogether 148,901 (27\%) workers have both piece-rate and time-rate earnings at least once during our 13-year observation period. Interestingly 135,128 of these workers share their hours between piece and time rates within the same quarter at some point in their career. Typically, workers are on piece rate for a specific task (e.g. building a brick wall) and once the task is completed they work on time rates until the next piece rate assignement is measured and priced.

Table 1 gives the descriptives statistics on workers who work positive number of hours on piece rates and on workers who have no piece-rate earnings. Data is pooled over 13 years and the unit of observation is a person-year combination. As shown in the table piece rates earnings of men are on average 27 ( 7 for women) percent higher than time rate earnings. Also time-rate earnings are higher for those earning also piece rates indicating that the piece-rate workers are not a randomly selected group of workers. Average age and education of piece-rate workers is not very different from other workers. Men working on piece rates have on average shorter tenure than other men, among women the piece-rate workers have longer tenure. 
In line with previous evidence in Pekkarinen and Riddell [2008] the variation in the use of piece rates is mainly due to differences across firms. An average piece-rate worker is employed in a firm where $33 \%$ of co-workers also receive piece rates while the corresponding figure for time-rate workers is only $5 \%$. Piece rates are also more extensively used smaller firms. In addition, the use of piece rates varies across industries. Most piece-rate workers are employed in technology, sawmill, construction and clothing industries.

\section{Age-profile of piece vs. time rate earnings}

Figure 1 plots the age profiles of hourly piece-rate earnings for men and women in the whole manufacturing worker population during 1990-2002. Both profiles are derived from OLS-regressions where variation over time is controlled for by including the year dummies and variation across firms by including the firm fixed-effects. For comparison, we also plot the age profile of time-rate wages, separately for workers who also have piece-rate earnings in and for workers who are never observed on piece rates.

Both time rate and piece rate earnings follow familiar concave age profiles. They increase rapidly with age up to about age 30 and reach their maximum around age 45. However, the age-profile of piece rate earnings is flatter than that of time rate wages, particularly among women. Tables $2 \mathrm{a}$ and $2 \mathrm{~b}$ report summary statistics for the growth of time and piece rates within specified age range. For men piece rates (time rates) increase by 0.03 (0.06) log points between ages 30 and 45 and then decline by 0.03 (0.01) log points between ages 45 and 60. For women piece rates (time rates) only increase by $0.01 \%$ (0.03) between ages 30 and 45 and decline by 0.01 between ages 45 and 60 where as time rates do not decline at all. In addition, piece rate earnings are higher than time rate earnings at all ages. Time-rate earnigs are slightly higher for those who also work on piece rates than for those who always work on time rates, indicating positive selectivity into piece-rate work. We deal 
with this selection problem in the following section.

\section{Effect of age on productivity}

\subsection{Method}

Our goal is to estimate the effect of age on individual productivity, proxied by piece-rate earnings, based on the following equation:

$\log \left(w_{i t}^{\text {piece }}\right)=\alpha_{i}+\Phi_{k}^{\text {piece }} D_{k}\left(\right.$ age $\left._{i t}\right)+\Pi_{t}^{\text {piece }} D_{t}\left(\right.$ year $\left._{i t}\right)+\Omega_{f}^{\text {piece }} D_{f}\left(\right.$ firm $\left._{i t}\right)+\epsilon_{i t}^{\text {piece }}$

where $w_{i t}^{\text {piece }}$ is piece-rate compensation per hour in year $t . D_{k}$ is a full set of one-year age dummies, $D_{t}$ a full set of year dummies, and $D_{f}$ a full set of firm dummies. We are mainly interested in recovering unbiased estimates for the parameter vector $\Phi_{k}$ i.e. the coefficients of the age dummies.

An obvious caveat in our approach is that those who receive piece rates are a self-selected group that is likely to have higher productivity than average workers. ${ }^{4}$ If selectivity were independent of age, the age - productivity profiles could still be consistently estimated, though the results would not necessarily be generalizable to workers who do not work on piece rates. If the selection process is different at different ages or perhaps at the different stages of the career, even including the worker fixed-effects would not generate unbiased estimates for the age profiles. ${ }^{5}$ Another important reason preventing the use of worker fixed-effects is that they would be perfectly collinear with the age and time effects. The worker fixed-effects only vary within cohort and identifying them separately from the time and age effects is just as hard as identifying separately age, time and cohort effects. We could identify

\footnotetext{
${ }^{4}$ For a theoretical illustration of this point see the model in Lazear $\mid 1986$.

${ }^{5}$ Technically $E\left(\epsilon_{i t}^{\text {piece }} \mid w_{i t}^{\text {piece }}>0, \alpha_{i}\right)$ may still depend on age. Methods for coping with selectivity problem in fixed effects models are discussed by Wooldridge $\mid 1995$ but they usually involve explicit modelling of the selectivity process and parametric corrections for selectivity bias.
} 
the model by imposing parametric restrictions on the effects of time or age but the resulting estimates would be entirely dependent on these arbitrary restrictions.

Our approach is based on a simple selectivity correction similar to one that would be used with cross-section data. We assume that piece-rate earnings depend on age and year and may vary across firms. To identify the model we assume that firm effects on piece-rate earnings are constant over time and that the firm-year interactions can hence be omitted from the main equation. Essentially we assume that firms switch from piece rates to time rates and vice versa for reasons that are unrelated to changes in individuallevel wages or productivity. This is a similar assumption to the one used by Lazear $|2000|$ to estimate the effect of piece rate contracts on productivity using data on a single firm.

Estimating several thousand firm effects and their interactions with the year effects in a standard probit selection model is not computatonally feasible. Therefore we use the approach by Olsen $|1980|$ and estimate the selection equation using a linear probablity model absorbing the firm-year interactions in a "fixed effect".

More formally Olsen |1980| specifies equation of interest as

$$
y_{i}=X_{i} \beta+u_{i}
$$

and assumes that $y_{i}$ is observed if $s_{i}=1$ where

$$
s_{i}=1 \text { iff } \nu_{i}<Z_{i} \gamma
$$

If $\nu_{i}$ follows a uniform distribution, $P\left(s_{i}=1\right)=Z_{i} \gamma$, and vector $\gamma$ can be consistently estimated using the linear probability model. Under the usual assumption that the conditional expectation of $u_{i}$ is a linear function of $\nu_{i}$, Olsen $|1980|$ shows that 


$$
E\left(y_{i} \mid X_{i}, \nu_{i}<Z_{i} \gamma\right)=X_{i} \beta+\rho \sigma_{u} \sqrt{3}\left(Z_{i} \gamma-1\right)
$$

Consistent estimates for $\beta$ can therefore be obtained by regressing $y_{i}$ on $X_{i}$ and $\left(Z_{i} \hat{\gamma}-1\right)$. As in the probit selection model, the standard errors need to be adjusted because of the generated regressor $\left(Z_{i} \hat{\gamma}-1\right)$ but otherwise the procedure is simple. In our case the vector $X_{i}$ includes age, year, and firm effects and vector $Z_{i}$ also the interactions between firm and year that are excluded from $X_{i}$.

Even though the estimation of the productivity age-profile requires somewhat strong assumptions, we are able to directly estimate the age profile of the productivity-wage gap using within worker variation in payment schemes. As noted above some workers have both time-rate and piece rate earnings within the same quarter. For these workers, we can simply calculate the difference between hourly piece rate and time rate earnings and plot the age profile of this gap.

\subsection{Selectivity corrected piece rate age profiles}

In figure 2 we produce selectivity-corrected estimates based on (2). In addition to displaying the age-profiles in the entire manufacturing industry, we estimate separately the age-productivity profiles in industries with largest numbers of piece rate workers. To aid comparison across industries all figures are normalized by ommitting the first age dummy. As the figures include the firm effects, the differences in the earnings levels across industries are not informative, but the slopes can be compared.

According to figure 2 selectivity correction has only a small effect on the age-productivity profile when data on all industries is pooled together. Productivity increases rapidly between ages twenty and thirty, but grows only by 0.01 log points between ages 30 and 45 for both men and women. Produc-

tivity peaks at age 43 and then declines by 0.03 log points between ages 43 
and 60 (0.01 for women). However, this aggregate age - productivity profile hides heterogeneity across industries. In the technology industry which employs the largest number of piece rate workers the age profiles resembles the aggregate age profile. However, in eg. construction (textiles for women) the productivity growth between ages 30 and 40 is much stronger and the decline after age 40 much steeper. Analysing the reasons for the across industry differences would require additional data on tasks performed under piece rates in different industries. A potential explanation would be that productivity declines with age more rapidly in physically demanding tasks.

\subsection{Age profile of the within worker piece rate - time rate gap}

The comparison of age-profiles of piece and time rates in figure 1 reveals that the gap between piece rates and times rates diminishes with age. This would suggest that younger workers are relatively "cheaper" than prime-age workers in the sense that the gap between their piece rate and fixed rate wages is higher. However, this comparison is potentially confounded by agevarying selection into piece rates in the same way than the estimates of the age profiles.

One way to deal with this problem is use data on workers who we observe on both time and piece rates within a single year. For these workers, we can calculate the contemporaeus within-worker difference between the piece rates and the time rates. Figure 3 presentes the age coefficients from the regression where these within-worker piece-rate premiums are regressed on a full set of age, year, and firm dummies. The results confirm the conclusion that the gap between piece rates and time rates decreases with age. Table 3 reports the average predicted gaps within specified age range. The gap is approximately $0.02 \mathrm{log}$ points higher for young workers than it is for prime age workers. However, figure 3 also confirms that senior workers above age 55 are not dramatically more "expensive" than the prime age workers. Among 
the male workers the gap is slightly smaller for workers older than 50, but this difference is small and only marginally significant. For women we do not observe any decrease in the productivity-wage gap after age 30 .

\section{Conclusions}

Our results indicate that aging has no dramatic effects on productivity in tasks where worker output can be inferred from piece-rate earnings. Productivity increases rapidly up to age 30, and peaks around age 45 but declines only sligthly after that. Younger workers paid by time-rates are relatively cheaper than older workers compared to the productivity differences but this gap disappears after age 40 .

As productivity growth depends on innovative activities that are typically not rewarded by piece rates, it would be premature to conclude that population aging has no impacts on aggregate productivity. Still finding that aging has only modest impact on productivity in wide variety of tasks should probably mitigate some concerns on the effect of population aging on productivity.

\section{References}

A. Borsch-Supan and M. Weiss. Productivity and the age composition of work teams: evidence from the assembly line. MEA Discussion Paper No. 148-0\%, 2008.

B. Crépon, N. Deniau, and S. Pérez-Duarte. Wages, productivity and worker characteristics: A french perspective. Working Papers, 2003.

B. Dostie. Wages, productivity and aging. De Economist, pages 1-20, 2011.

R.C. Fair. How fast do old men slow down? The Review of Economics and Statistics, pages 103-118, 1994. 
J. Feyrer. Demographics and productivity. The Review of Economics and Statistics, 89(1):100-109, 2007.

L. Flabbi and A. Ichino. Productivity, seniority and wages: new evidence from personnel data. Labour Economics, 8(3):359-387, 2001.

D.W. Galenson and R. Jensen. Young geniuses and old masters: The life cycles of great artists from masaccio to jasper johns. Technical report, National Bureau of Economic Research, 2001.

J.K. Hellerstein, D. Neumark, and K.R. Troske. Wages, productivity, and worker characteristics: Evidence from plant-level production functions and wage equations. Journal of Labor Economics, 17(3):409-446, 1999.

P. Ilmakunnas and M. Maliranta. Technology, labour characteristics and wage-productivity gaps. Oxford Bulletin of Economics and Statistics, 67 (5):623-645, 2005.

E.P. Lazear. Salaries and piece rates. Journal of Business, pages 405-431, 1986.

E.P. Lazear. Performance pay and productivity. The American Economic Review, 2000.

E.P. Lazear and R.L. Moore. Incentives, productivity, and labor contracts. The Quarterly Journal of Economics, 99(2):275, 1984.

J.L. Medoff and K.G. Abraham. Experience, performance, and earnings. The Quarterly Journal of Economics, 95(4):703, 1980.

J.L. Medoff and K.G. Abraham. Are those paid more really more productive? the case of experience. Journal of Human Resources, pages 186-216, 1981.

R.J. Olsen. A least squares correction for selectivity bias. Econometrica: Journal of the Econometric Society, pages 1815-1820, 1980. 
S.M. Oster and D.S. Hamermesh. Aging and productivity among economists. Review of Economics and Statistics, 80(1):154-156, 1998.

T. Pekkarinen and C. Riddell. Performance pay and earnings: Evidence from personnel records. Industrial and Labor Relations Review, pages 297-319, 2008.

J. Tang and C. MacLeod. Labour force ageing and productivity performance in canada. Canadian Journal of Economics/Revue canadienne d'économique, 39(2):582-603, 2006.

J.C. Van Ours. Will you still need me: When i'm 64? De Economist, 157 (4):441-460, 2009.

B.A. Weinberg and D.W. Galenson. Creative careers: The life cycles of nobel laureates in economics. Technical report, National Bureau of Economic Research, 2005.

J.M. Wooldridge. Selection corrections for panel data models under conditional mean independence assumptions. Journal of Econometrics, 68(1): 115-132, 1995. 

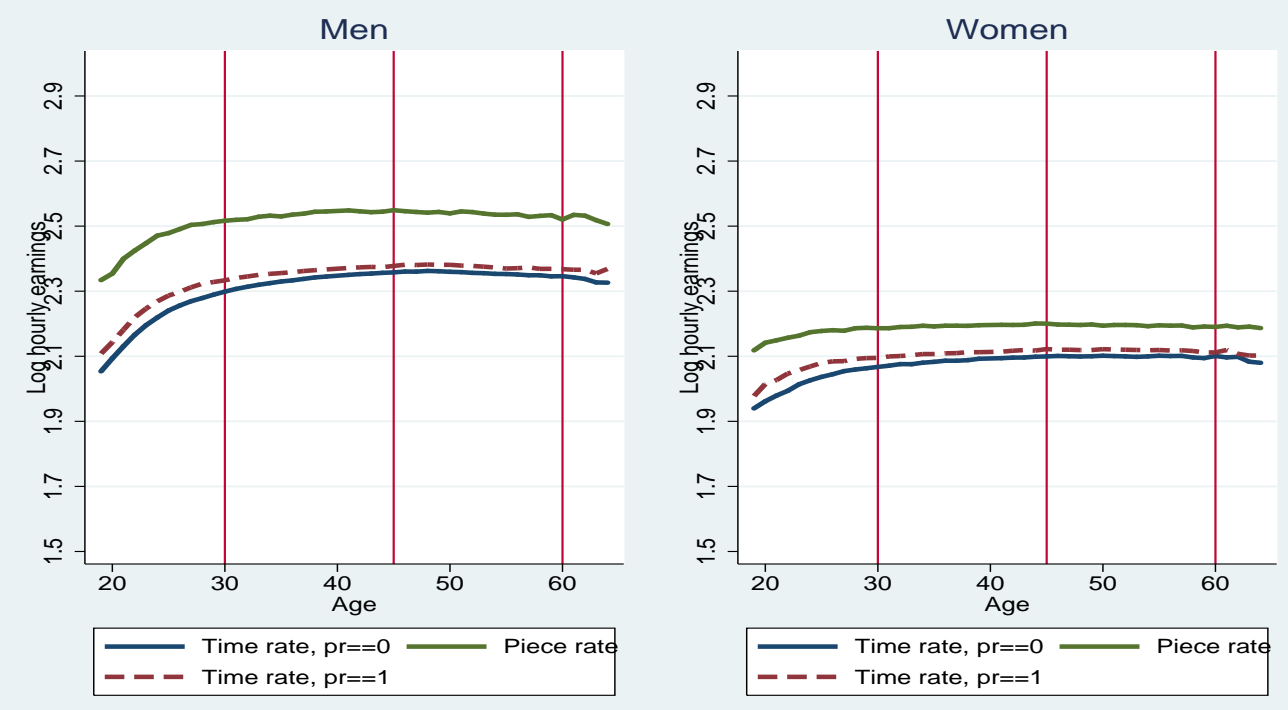

Figure 1: Age profiles of time rates and piece rates.

Predicted values from an OLS regression of hourly earnings on year and firm dumies, and piece-rate indicators interacted with the age dummies. 

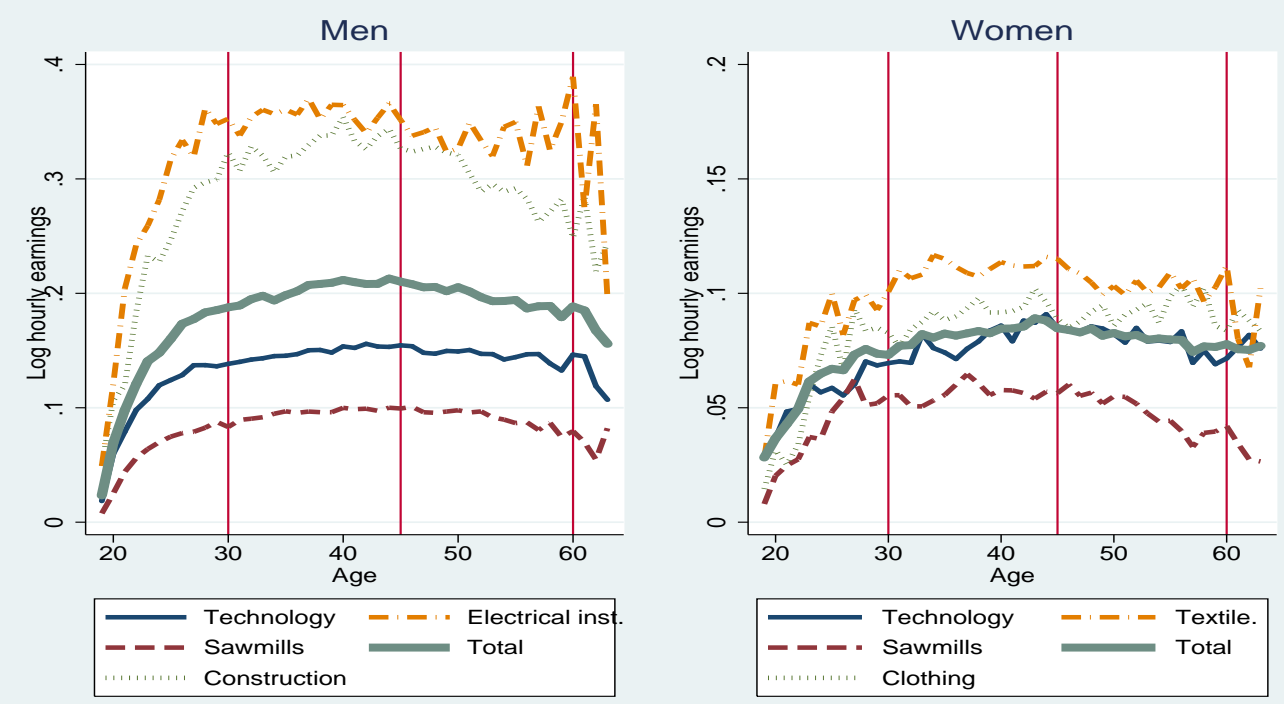

Figure 2: Selectivity corrected age profiles of piece rates in different industries 

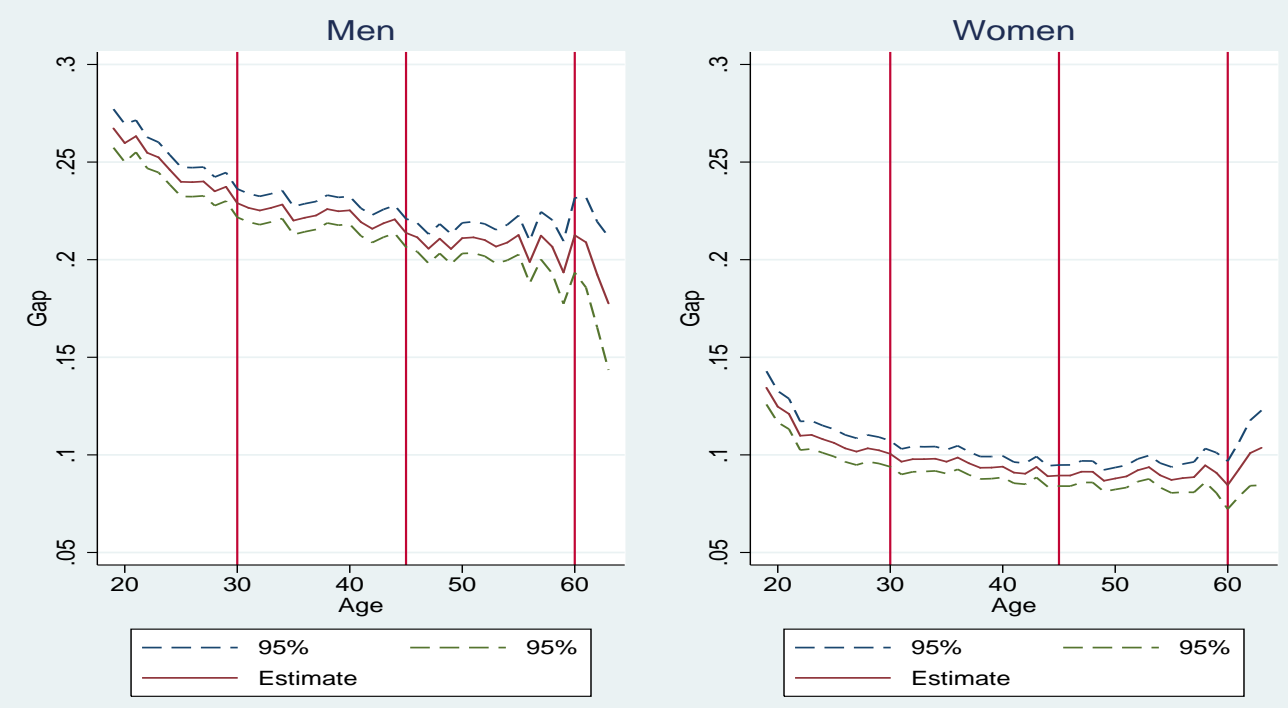

Figure 3: Within worker gaps between time rates and piece rates by age for men and women in manufacturing industries. 
Table 1. Descriptive statistics by gender and piece rate status

\begin{tabular}{|c|c|c|c|c|}
\hline \multirow[t]{2}{*}{ Variable } & \multicolumn{2}{|c|}{ Men } & \multicolumn{2}{|c|}{ Women } \\
\hline & No piece rate hours & Piece rate hours & No piece rate hours & Piece rate hours \\
\hline \multirow[t]{2}{*}{ Av. hourly earnings } & 10.30 & 11.16 & 8.63 & 8.69 \\
\hline & $(2.47)$ & $(3.40)$ & $(1.74)$ & $(1.47)$ \\
\hline \multirow[t]{2}{*}{ Hourly time rate } & 9.84 & 10.32 & 8.26 & 8.37 \\
\hline & (26.19) & (20.95) & (23.89) & $(19.17)$ \\
\hline \multirow[t]{2}{*}{ Hourly piece rate } & & 12.54 & & 8.87 \\
\hline & & $(7.85)$ & & $(2.01)$ \\
\hline \multirow[t]{2}{*}{ Age } & 39.18 & 38.95 & 41.15 & 41.98 \\
\hline & $(10.78)$ & $(10.15)$ & $(11.20)$ & $(10.16)$ \\
\hline \multirow[t]{2}{*}{ Tenure } & 12.04 & 10.26 & 10.07 & 11.10 \\
\hline & $(10.68)$ & $(9.71)$ & $(9.56)$ & $(9.27)$ \\
\hline \multirow[t]{2}{*}{ Years of education } & 11.08 & 11.08 & 10.65 & 10.49 \\
\hline & $(1.54)$ & (1.49) & (1.69) & $(1.61)$ \\
\hline \multirow[t]{2}{*}{ Firm size } & 1797 & 702 & 2208 & 679 \\
\hline & (3386) & (1037) & $(4351)$ & $(1045)$ \\
\hline \multirow[t]{2}{*}{ Co-workers' piece rate share } & 0.05 & 0.33 & 0.06 & 0.34 \\
\hline & $(0.13)$ & $(0.28)$ & $(0.13)$ & $(0.25)$ \\
\hline \multirow[t]{8}{*}{ Four largest industries } & 1. Technology & 1. Technology & 1. Technology & 1. Technology \\
\hline & $N=443,800$ & $\mathrm{~N}=221,629$ & $\mathrm{~N}=121,795$ & $\mathrm{~N}=61,129$ \\
\hline & 2. Paper & 2. Sawmills & 2. Paper & 2. Sawmills \\
\hline & $\mathrm{N}=251,774$ & $\mathrm{~N}=95,591$ & $N=51,608$ & $\mathrm{~N}=30,084$ \\
\hline & 3. Printing & 3. Buliding constr. & 3. Printing & 3. Clothing \\
\hline & $\mathrm{N}=69,061$ & $\mathrm{~N}=92,267$ & $\mathrm{~N}=41,815$ & $N=27,396$ \\
\hline & 4. Postal Services & 4. Electrical install. & 4. Postal Services & 4. Textile \\
\hline & $\mathrm{N}=53,080$ & $\mathrm{~N}=34,386$ & $\mathrm{~N}=35,442$ & $\mathrm{~N}=21,167$ \\
\hline
\end{tabular}

Note: Earnings are converted to the 2002 level using the consumer price index. Standard deviations are reported in parentheses.

Table 2a. Summary statistics of wage growth by age in different payment schemes. Men.

\begin{tabular}{lccc}
\hline Age range & $\begin{array}{c}\text { Time rates } \\
\text { Time rate workers }\end{array}$ & $\begin{array}{c}\text { Time rates } \\
\text { Piece rate workers }\end{array}$ & Piece rates \\
\hline $\mathbf{1 9 - 3 0}$ & 0.245 & 0.221 & 0.185 \\
$\mathbf{3 0 - 4 5}$ & 0.057 & 0.043 & 0.032 \\
$\mathbf{4 5 - 6 0}$ & -0.01 & -0.006 & -0.028 \\
\hline
\end{tabular}

Note: Cells report the accumulated predicted wage growth within the age range. Predicted growth is calculated from coefficients of a regression where log time and piece rate wages are regressed on age, year, and a full set of firm dummies. In column 1 , only data on those workers who work exclusively time rates are used. In column 3, only data on those workers who also work a positive number of piece rates are used.

Table 2b. Summary statistics of wage growth by age in different payment schemes. Women

\begin{tabular}{lccc}
\hline Age range & $\begin{array}{c}\text { Time rates } \\
\text { Time rate workers }\end{array}$ & $\begin{array}{c}\text { Time rates } \\
\text { Piece rate workers }\end{array}$ & Piece rates \\
\hline $\mathbf{1 9 - 3 0}$ & 0.125 & 0.117 & 0.068 \\
$\mathbf{3 0 - 4 5}$ & 0.033 & 0.028 & 0.013 \\
$\mathbf{4 5 - 6 0}$ & 0.000 & -0.011 & -0.007 \\
\hline
\end{tabular}

Note: Cells report the accumulated predicted wage growth within the age range. Predicted growth is calculated from coefficients of a regression where log time and piece rate wages are regressed on age, year, and a full set of firm dummies. In column 1, only data on those workers who work exclusively time rates are used. In column 3, only data on those workers who also work a positive number of piece rates are used.

Table 3. Summary statistics of the within worker gap between piece and time rates

\begin{tabular}{lcc}
\hline Age range & Men & Women \\
\hline $\mathbf{1 9 - 3 0}$ & 0.247 & 0.110 \\
$\mathbf{3 0 - 4 5}$ & 0.223 & 0.095 \\
$\mathbf{4 5 - 6 0}$ & 0.207 & 0.091 \\
\hline
\end{tabular}

Note: Cells report the accumulated the average predicted within work gap between log piece and time rates within the age range.

Predicted gaps are calculated from coefficients of a regression where within worker log gap is regressed on age, year, and a full set of firm dummies. 


\section{APPENDIX TABLES}

Table A1. Age profiles of time rate and piece rate wages, men.

\begin{tabular}{|c|c|c|c|c|c|c|}
\hline \multirow[b]{2}{*}{ Age } & \multicolumn{2}{|c|}{$\begin{array}{c}\text { Time rates } \\
\text { Time-rate workers }\end{array}$} & \multicolumn{2}{|c|}{$\begin{array}{c}\text { Time rates } \\
\text { Piece-rate workers }\end{array}$} & \multicolumn{2}{|c|}{$\begin{array}{c}\text { Piece rates } \\
\text { Piece-rate workers }\end{array}$} \\
\hline & Coeff. & S.E. & Coeff. & S.E. & Coeff. & S.E. \\
\hline 19 & -0.282 & 0.002 & -0.262 & 0.003 & -0.212 & 0.005 \\
\hline 20 & -0.242 & 0.002 & -0.227 & 0.003 & -0.192 & 0.004 \\
\hline 21 & -0.209 & 0.001 & -0.188 & 0.002 & -0.146 & 0.004 \\
\hline 22 & -0.175 & 0.001 & -0.150 & 0.002 & -0.121 & 0.003 \\
\hline 23 & -0.148 & 0.001 & -0.123 & 0.002 & -0.099 & 0.003 \\
\hline 24 & -0.124 & 0.001 & -0.101 & 0.002 & -0.075 & 0.003 \\
\hline 25 & -0.101 & 0.001 & -0.083 & 0.002 & -0.068 & 0.003 \\
\hline 26 & -0.086 & 0.001 & -0.072 & 0.002 & -0.055 & 0.003 \\
\hline 27 & -0.071 & 0.001 & -0.058 & 0.002 & -0.043 & 0.003 \\
\hline 28 & -0.061 & 0.001 & -0.047 & 0.002 & -0.040 & 0.003 \\
\hline 29 & -0.050 & 0.001 & -0.042 & 0.002 & -0.034 & 0.003 \\
\hline 30 & -0.040 & 0.001 & -0.037 & 0.002 & -0.030 & 0.003 \\
\hline 31 & -0.032 & 0.001 & -0.030 & 0.002 & -0.027 & 0.003 \\
\hline 32 & -0.024 & 0.001 & -0.025 & 0.002 & -0.025 & 0.003 \\
\hline 33 & -0.016 & 0.001 & -0.020 & 0.002 & -0.018 & 0.003 \\
\hline 34 & -0.012 & 0.001 & -0.017 & 0.002 & -0.014 & 0.003 \\
\hline 35 & -0.007 & 0.001 & -0.015 & 0.002 & -0.017 & 0.003 \\
\hline 36 & -0.003 & 0.001 & -0.012 & 0.002 & -0.011 & 0.003 \\
\hline 37 & 0.003 & 0.001 & -0.008 & 0.002 & -0.009 & 0.003 \\
\hline 38 & 0.009 & 0.001 & -0.006 & 0.001 & -0.003 & 0.003 \\
\hline 39 & 0.011 & 0.001 & -0.004 & 0.001 & -0.002 & 0.003 \\
\hline 40 & \multicolumn{2}{|c|}{ Consrained to 0} & \multicolumn{2}{|c|}{ Consrained to 0} & \multicolumn{2}{|c|}{ Consrained to 0} \\
\hline 41 & 0.017 & 0.001 & 0.001 & 0.001 & 0.002 & 0.003 \\
\hline 42 & 0.020 & 0.001 & 0.003 & 0.001 & -0.001 & 0.003 \\
\hline 43 & 0.022 & 0.001 & 0.004 & 0.002 & -0.004 & 0.003 \\
\hline 44 & 0.024 & 0.001 & 0.003 & 0.002 & -0.002 & 0.003 \\
\hline 45 & 0.024 & 0.001 & 0.007 & 0.002 & 0.002 & 0.003 \\
\hline 46 & 0.027 & 0.001 & 0.011 & 0.002 & -0.001 & 0.003 \\
\hline 47 & 0.027 & 0.001 & 0.010 & 0.002 & -0.003 & 0.003 \\
\hline 48 & 0.029 & 0.001 & 0.011 & 0.002 & -0.005 & 0.003 \\
\hline 49 & 0.028 & 0.001 & 0.011 & 0.002 & -0.003 & 0.003 \\
\hline 50 & 0.025 & 0.001 & 0.011 & 0.002 & -0.008 & 0.003 \\
\hline 51 & 0.025 & 0.001 & 0.008 & 0.002 & -0.002 & 0.003 \\
\hline 52 & 0.023 & 0.001 & 0.007 & 0.002 & -0.004 & 0.003 \\
\hline 53 & 0.021 & 0.001 & 0.005 & 0.002 & -0.008 & 0.003 \\
\hline 54 & 0.020 & 0.001 & 0.002 & 0.002 & -0.012 & 0.004 \\
\hline 55 & 0.020 & 0.001 & -0.001 & 0.002 & -0.012 & 0.004 \\
\hline 56 & 0.020 & 0.002 & 0.000 & 0.002 & -0.011 & 0.004 \\
\hline 57 & 0.016 & 0.002 & 0.002 & 0.003 & -0.018 & 0.004 \\
\hline 58 & 0.016 & 0.002 & -0.002 & 0.003 & -0.015 & 0.005 \\
\hline 59 & 0.014 & 0.002 & -0.002 & 0.003 & -0.013 & 0.006 \\
\hline 60 & 0.014 & 0.002 & -0.003 & 0.004 & -0.027 & 0.006 \\
\hline 61 & 0.010 & 0.003 & -0.005 & 0.005 & -0.012 & 0.008 \\
\hline 62 & 0.005 & 0.003 & -0.005 & 0.006 & -0.015 & 0.009 \\
\hline 63 & -0.006 & 0.004 & -0.016 & 0.007 & -0.029 & 0.010 \\
\hline 64 & -0.007 & 0.004 & -0.002 & 0.008 & -0.040 & 0.012 \\
\hline Constant & 2.328 & 0.001 & 2.370 & 0.001 & 2.546 & 0.002 \\
\hline
\end{tabular}

Note: Coefficients are OLS estimates of age dummies from a regression of log hourly earnings on year and firm dummies and age interacted with indicators of i) time-rate pay for those working only on time rates, ii) time-rate pay for those earning also piece rates and iii) piece-rate pay. Coefficient of age 40 is restricted to zero and hence the other coefficients measure the difference in hourly earnings to hourly earnings at age 40 under each pay system. Standard errors are clustered at the person level. 
Table A2. Age profiles of time rates and piece rates, women.

\begin{tabular}{|c|c|c|c|c|c|c|}
\hline \multirow[b]{2}{*}{ Age } & \multicolumn{2}{|c|}{$\begin{array}{c}\text { Time rates } \\
\text { Time-rate workers }\end{array}$} & \multicolumn{2}{|c|}{$\begin{array}{c}\text { Time rates } \\
\text { Piece-rate workers }\end{array}$} & \multicolumn{2}{|c|}{$\begin{array}{c}\text { Piece rates } \\
\text { Piece-rate workers }\end{array}$} \\
\hline & Coeff. & S.E. & Coeff. & S.E. & Coeff. & S.E. \\
\hline 19 & -0.165 & 0.002 & -0.136 & 0.004 & -0.075 & 0.004 \\
\hline 20 & -0.145 & 0.002 & -0.099 & 0.004 & -0.052 & 0.004 \\
\hline 21 & -0.131 & 0.002 & -0.087 & 0.004 & -0.044 & 0.004 \\
\hline 22 & -0.119 & 0.002 & -0.067 & 0.003 & -0.036 & 0.003 \\
\hline 23 & -0.099 & 0.002 & -0.057 & 0.003 & -0.030 & 0.003 \\
\hline 24 & -0.087 & 0.002 & -0.045 & 0.003 & -0.019 & 0.003 \\
\hline 25 & -0.078 & 0.002 & -0.034 & 0.003 & -0.016 & 0.003 \\
\hline 26 & -0.069 & 0.002 & -0.030 & 0.003 & -0.013 & 0.003 \\
\hline 27 & -0.060 & 0.002 & -0.029 & 0.003 & -0.015 & 0.003 \\
\hline 28 & -0.052 & 0.002 & -0.022 & 0.003 & -0.007 & 0.003 \\
\hline 29 & -0.045 & 0.002 & -0.020 & 0.003 & -0.006 & 0.003 \\
\hline 30 & -0.041 & 0.002 & -0.019 & 0.003 & -0.007 & 0.003 \\
\hline 31 & -0.036 & 0.002 & -0.015 & 0.003 & -0.007 & 0.003 \\
\hline 32 & -0.031 & 0.002 & -0.014 & 0.003 & -0.004 & 0.003 \\
\hline 33 & -0.030 & 0.002 & -0.011 & 0.003 & -0.003 & 0.003 \\
\hline 34 & -0.025 & 0.002 & -0.008 & 0.002 & 0.000 & 0.003 \\
\hline 35 & -0.023 & 0.002 & -0.008 & 0.002 & -0.002 & 0.003 \\
\hline 36 & -0.020 & 0.002 & -0.005 & 0.002 & 0.000 & 0.003 \\
\hline 37 & -0.021 & 0.002 & -0.005 & 0.002 & 0.000 & 0.002 \\
\hline 38 & -0.018 & 0.002 & -0.002 & 0.002 & 0.000 & 0.002 \\
\hline 39 & -0.013 & 0.002 & -0.002 & 0.002 & 0.002 & 0.002 \\
\hline 40 & \multicolumn{2}{|c|}{ Consrained to 0} & \multicolumn{2}{|c|}{ Consrained to 0} & \multicolumn{2}{|c|}{ Consrained to 0} \\
\hline 41 & -0.010 & 0.002 & 0.000 & 0.002 & 0.003 & 0.002 \\
\hline 42 & -0.008 & 0.002 & 0.003 & 0.002 & 0.003 & 0.002 \\
\hline 43 & -0.009 & 0.002 & 0.004 & 0.002 & 0.003 & 0.002 \\
\hline 44 & -0.006 & 0.002 & 0.003 & 0.002 & 0.007 & 0.002 \\
\hline 45 & -0.005 & 0.002 & 0.008 & 0.002 & 0.007 & 0.002 \\
\hline 46 & -0.005 & 0.002 & 0.005 & 0.002 & 0.004 & 0.002 \\
\hline 47 & -0.005 & 0.002 & 0.006 & 0.002 & 0.003 & 0.002 \\
\hline 48 & -0.005 & 0.002 & 0.004 & 0.002 & 0.002 & 0.002 \\
\hline 49 & -0.005 & 0.002 & 0.005 & 0.002 & 0.004 & 0.002 \\
\hline 50 & -0.002 & 0.002 & 0.007 & 0.002 & 0.000 & 0.002 \\
\hline 51 & -0.003 & 0.002 & 0.006 & 0.002 & 0.002 & 0.003 \\
\hline 52 & -0.004 & 0.002 & 0.005 & 0.002 & 0.002 & 0.003 \\
\hline 53 & -0.006 & 0.002 & 0.005 & 0.002 & 0.002 & 0.003 \\
\hline 54 & -0.004 & 0.002 & 0.004 & 0.002 & -0.001 & 0.003 \\
\hline 55 & -0.002 & 0.002 & 0.004 & 0.002 & 0.001 & 0.003 \\
\hline 56 & -0.002 & 0.002 & 0.003 & 0.003 & 0.000 & 0.003 \\
\hline 57 & -0.003 & 0.002 & 0.004 & 0.003 & 0.001 & 0.003 \\
\hline 58 & -0.007 & 0.002 & 0.002 & 0.003 & -0.005 & 0.003 \\
\hline 59 & -0.008 & 0.003 & -0.003 & 0.004 & -0.002 & 0.004 \\
\hline 60 & -0.002 & 0.003 & -0.003 & 0.004 & -0.004 & 0.004 \\
\hline 61 & -0.008 & 0.003 & 0.005 & 0.005 & 0.000 & 0.005 \\
\hline 62 & -0.005 & 0.004 & -0.007 & 0.006 & -0.005 & 0.005 \\
\hline 63 & -0.022 & 0.005 & -0.012 & 0.007 & -0.003 & 0.007 \\
\hline 64 & -0.024 & 0.005 & -0.013 & 0.008 & -0.007 & 0.007 \\
\hline Constant & 2.097 & 0.001 & 2.116 & 0.002 & 2.195 & 0.002 \\
\hline
\end{tabular}

Note: Coefficients are OLS estimates of age dummies from a regression of log hourly earnings on year and firm dummies and age interacted with indicators of i) time-rate pay for those working only on time rates, ii) time-rate pay for those earning also piece rates and iii) piece-rate pay. Coefficient of age 40 is restricted to zero and hence the other coefficients measure the difference in hourly earnings to hourly earnings at age 40 under each pay system. Standard errors are clustered at the person level. 